\title{
Transition to Smart and Regenerative Urban Places (SRUP): Contributions to a New Conceptual Framework
}

\author{
Angeliki Peponi ${ }^{1,2, *(D)}$ and Paulo Morgado ${ }^{2}$ (D) \\ 1 Faculty of Environmental Sciences, Czech University of Life Sciences Prague, \\ 16500 Praha-Suchdol, Czech Republic \\ 2 Centre of Geographical Studies, Institute of Geography and Spatial Planning, Universidade de Lisboa, \\ 1600-276 Lisboa, Portugal; paulo@campus.ul.pt \\ * Correspondence: a.peponi@campus.ul.pt
}

Citation: Peponi, A.; Morgado, P. Transition to Smart and Regenerative Urban Places (SRUP): Contributions to a New Conceptual Framework. Land 2021, 10, 2. https://dx.doi.org/ 10.3390/land10010002

Received: 29 November 2020 Accepted: 21 December 2020 Published: 22 December 2020 Corrected: 22 February 2022

Publisher's Note: MDPI stays neutral with regard to jurisdictional claims in published maps and institutional affiliations.

Copyright: (c) 2020 by the authors. Licensee MDPI, Basel, Switzerland. This article is an open access article distributed under the terms and conditions of the Creative Commons Attribution (CC BY) license (https: / / creativecommons.org/ licenses/by/4.0/).

\begin{abstract}
Modern urbanism is called to face current challenges ranging from intensive demographic growth, economic and social stagnation to resources salvation and climate changes. Under the broader scope of sustainability, we argue that the transition to a holistic perspective of smart and regenerative planning and design is the way to face and yet to prevent these urban challenges. In doing so, we adopt systematic thinking to study the complexity of urban metabolisms at an urban place scale, emphasizing the ongoing coevolution of social-cultural-technological and ecological processes. Focusing on urban places, we give a city or region the sense of a place of stability, security, cultural and social interactions, and a sense of uniqueness. We plan and design innovative urban places that improve the environment and the quality of urban life, able to adapt and mitigate climate changes and natural hazards, leverage community spirit, and power a green-based economy. Designing the conceptual framework of smart and regenerative urban places we contribute to the field of modern urban studies helping practitioners, policymakers, and decision-makers to vision and adopt more environmental-friendly policies and actions using a user-centered approach.
\end{abstract}

Keywords: smart city; circular economy; urban metabolism; sustainability; resilience

\section{Introduction}

A city is an open system with interactions within the region and beyond, driven by endogenous and exogenous factors acting either short term or long term. Apart from factors like population growth and demographic changes the modern urbanization is essentially shaped by the impact of the international capital, the change to a new urban governance and institutional structures as well as by agglomeration forces [1]. These drivers stimulate changes in the scale, rate, location, form, and function of urbanization [1], generating spatial and temporal heterogeneity of social, biophysical and physical patterns and processes associated with physical, financial/economic, natural, human and social urban assets or resources [2].

Cities are expanding as urbanization is growing, and as McMahon affirmed, "growth is inevitable, and desirable, but destruction of community character is not" [3]. People, the social tissue, represent the social system that makes a city. Thus, cities are made by and for people, and the main goal should be to be fun and vibrant and make people happy [4,5]. Following MacMahon's idea of community, we second Batty (2018) [6] in his statement that we need to think of cities "as places where people come together to interact with one another" and with the surrounding environment. In line with Tuan (1977), we adopt the notion of a place as "an image of complex often ambivalent feelings (.. ), security and stability (.. ), a center of value built to satisfy particular needs (...), an organized world of meaning" [7]. Mang and Reed (2012) define urban places as "unique, multi-layered network of living systems within a geographic region that results from the complex interactions, through time, of the natural ecology and culture" [8]. In our work, we use the urban place as the scale for our study to highlighting 
the need to plan and design safe, secure cities with unique identities. Combined with the systematic approach we study urban systems' structure, functions and interactions, highlighting their complexity and proposing a novel way to tackle the impacts of modern urbanization.

A more defined mention of the Urban Systems concept can be found in Central Place Theory (CPT), developed by Christaller in 1933 and Lösch in 1940 [9]. In short, CPT attempts to explain space arrangement, size, and distribution of settlements/towns in the belief that there is some sort of order principle governing the distribution [10]. In the 1950s, the concept of urban systems started to be formed by applying the general system theory and cybernetics to soft social sciences. Main contributors to this growing interdisciplinary field of studies, supporting the idea that phenomena of interest in various disciples can be articulated as systems, were Ludwig von Bertalanffy in biology and Norbert Weiner in engineering [11]. Different parts and elements structure a system, and through their interactions, the system functions are generated to maintain the system working. Within the general system, negative feedback occurs when the system functions reinforce the equilibrium structure to keep the systems resilient and sustainable over time [12,13]. While general systems tend to be structurally static, ordered hierarchically (systems parts, elements), and existing in equilibrium to be optimum functional, most systems, indeed biological and human systems, are subject to positive feedback [12]. When a disturbance continues to force the system to move away from its earlier state, positive feedback pushes the system dynamics leading it to an entirely new state in contrast with the negative feedback, which brings the system to its pre-disturbance state [13].

By the mid-1970s, system theory applied in cities and city planning has appeared lifeless and the complexity science concept started to be developed gradually [12]. According to Wilson $(2000)$, Warren Weaver $(1948,1958)$ first distinguished simple (or general) systems as these that require a small number of variables to describe them and complex systems that require a large number of variables. Weaver further subdivided complex systems into those of disorganized complexity and those of organized complexity [14]. Before the 1960s, the available tools for quantitative analysis were limiting scientists to involve linear approximation in their analysis. Later, in the mid-1990s, we witnessed the emergence of an interdisciplinary science-based approach and analogies coming from philosophies of sciences, along with the ubiquity of computational capability in all scientific branches, which led to what became known as nonlinear dynamics methods. In favor of the nonlinear dynamics approach lies the notion that optimizing and defining a system through design, management, and control is suitable for solving human problems [12,13].

Based on the literature, salient concepts in urban complexity have appeared, namely: emergence systems; self-organization; non-linearity; evolutionary dynamics; adaptive behavior; and hierarchical ordering properties [15]. Among the various existing methods to explore and analyze urban complexity are the application of agent-based models, cellular automata, graph theory, fractal theory, spatial network analysis, urban scaling, and Bayesian belief networks [16,17]. These methods describe the urban complexity adopting urban form perspectives to study urban pattern changes, focusing on an urban subsystem component. The fact that a city cannot exist in isolation but only as part of a system of cities, and the elements of the city's urban systems exist only through their interactions, make the urban systems complex $[18,19]$. Thus, to fully understand and prepare the next generation of cities, we need to re-think cities on an inter-disciplinarily base and to launch a debate framed by this new challenging-context of global urbanization, urban sprawl, networked cities [20].

In this paper we are proposing a new conceptual framework for an integrated and expanded systematic analysis of urban places under an urban metabolism perspective, a changing paradigm of urban planning and design to face urban complexity challenges. Moving from the mechanistic approach that has been used for more than half a century in urban planning, we adopt the urban metabolism approach to capture holistically the positive feedback of nonlinear system dynamics. Peponi and Morgado (2020), conducting 
a systematic extensive literature review, have recently proven that smart and regenerative urban growth concepts have been approached separately [21]. This paper intends to demonstrate that by integrating them, we improve people's quality of life and public health in urban places through a more holistic and interdisciplinary urban planning and design.

This paper is organized as follows: After this introduction, Section 2 presents the synthesis of our novel conceptual framework. Starting with Section 2.1, we present urban places as metabolic complex systems applying the urban metabolism approach to our framework. We then demonstrate in Section 2.2 urban places as smart complex systems in line with the smart city concept, followed by Section 2.3, which represents urban places as regenerative complex systems in line with regenerative design of circular metabolisms. In Section 3, we integrate our key concepts into a new holistic conceptual framework adopting a systematic and metabolic thinking. Section 4 unfolds the main challenges related to the framework's implementation and Section 5 draws the conclusions upon it.

\section{Conceptualizing a Smart-Regenerative Framework for Urban Complex Places}

Nowadays, it is essential to adopt a different way to plan and design urban systems' complexity to tackle the current urban challenges, accepting that urban systems are dynamic and evolving out off-equilibrium. Through a systematic review of the literature based on bibliometric network analysis, Peponi and Morgado (2020) have identified that there is an absence of conceptual continuity between smart and regenerative urban growth/ development. Here, we attempt to synthesize these separate strands of literature into a novel holistic and integrated conceptual framework adopting an urban metabolism systems-based approach. In this way, we contribute to planning and designing future urban places bridging the environment and people, tackling pressures on resources, and being resilient to social-economic and environmental challenges.

In line with Jabareen, we perceive a conceptual framework as a network of linked concepts where each concept has an integral role instead of just been a collection of concepts [22]. We use a two-fold methodology based on grounded theory to conduct our conceptual framework. In the first part of our conceptual analysis, we demonstrate each pillar concept's unique characteristics, functions, and contributions to face the current urban challenges. In the second part, we integrate these concepts into one new conceptual framework pinpointing their node-bridge and analyzing the interplay among their components. The methodology we followed for building the smart and regenerative urban places (SRUP) conceptual framework is depicted in Figure 1.

\subsection{Urban Places As Metabolic Complex Systems}

In this subsection, we define urban places as metabolic complex systems, and we explain why adopting the urban metabolism approach in our conceptual analysis is essential to tackle current urban challenges. Starting to unfold the characteristic of urban metabolic systems, we conduct a comparative analysis of how the concept of urban metabolism has been used to support urban sustainability over time in relation to other disciplines.

The metaphor of metabolism is used to liken a city as a living organism. The first mention of the term metabolism in that way (Stoffwechsel) was made by Karl Marx in 1883, as "a process between man and nature, a process by which man, through his own actions, mediates, regulates and controls the metabolism between himself and nature". He observed an "irreparable rift" caused by capitalistic production and the city's antagonistic division and rural area. Thus it is essential to "govern the human metabolism with nature in a rational way" [23]. The Chicago School of Sociology in the 1920s-1930s uses ecology metaphors best known through the works of Park, Burgess, and McKenzie. Metaphors such as "physical growth", cities having "metabolism, pulse, a heart, erogenous zones", ecological theoretical concepts such as succession, symbiosis, competition, and adaptation, have been used to explain the urban expansion from the city center to suburbs. This expansion forms concentric circles, analyzing the spatial distribution of different social groups as "invasion-succession cycles" [24,25]. 


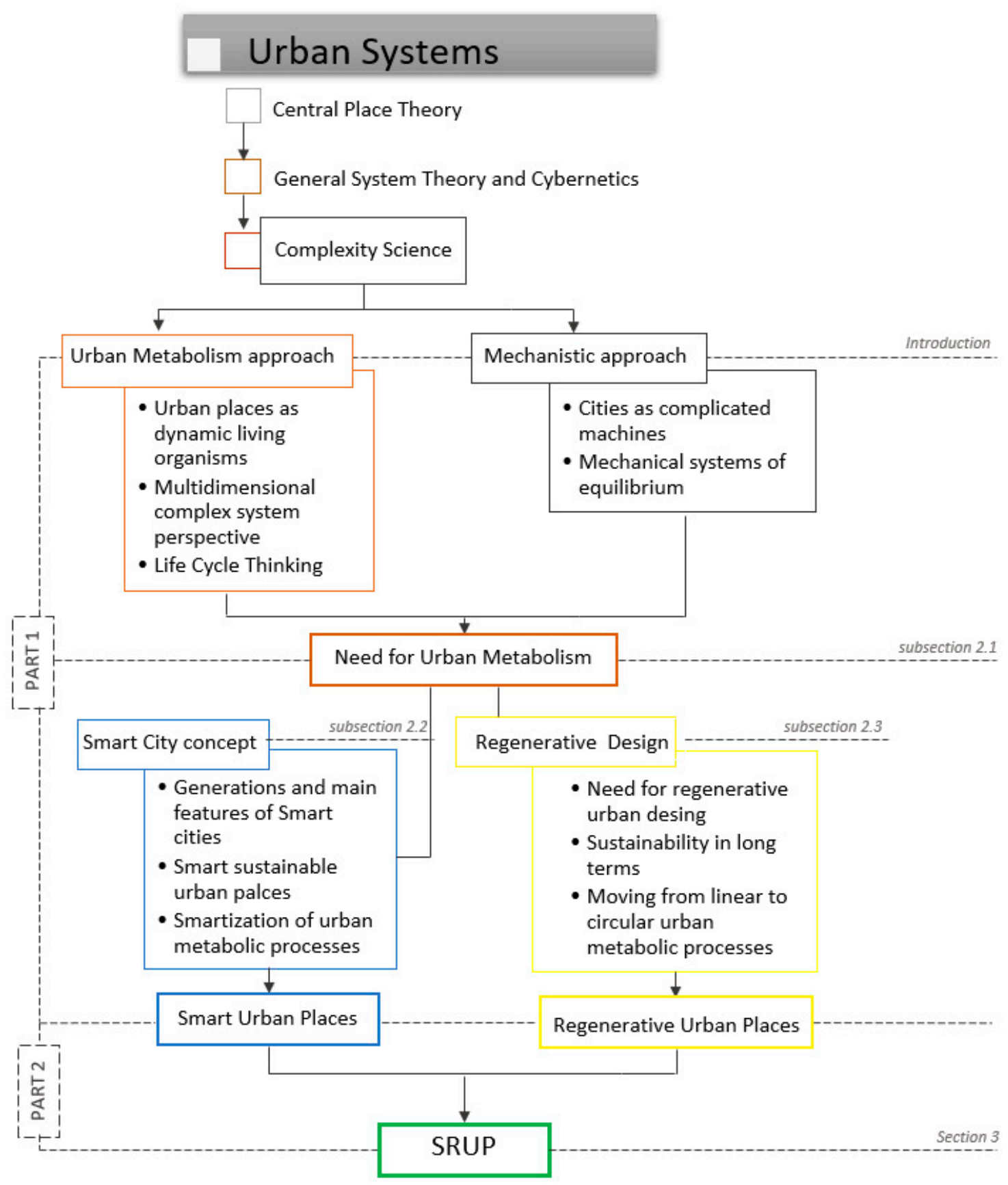

Figure 1. Conceptual framework analysis of Smart and Regenerative Urban Places (SRUP).

In 1965s, Wolman, in his work "The Metabolism of Cities," first conceived the concept of urban metabolism to support cities' sustainable development. A city is a closed system that converts inputs to outputs, or in other words, metabolizes resources to waste [25,26]. After this, the term has been used from two different schools. The first focuses on the energy equivalents, and the second attempts to describe urban metabolism under a broader approach expressing the flows of water, materials, and nutrients as mass fluxes [27]. In 2007 Kennedy, following Wolman's work, updates urban metabolism as "the sum total of the technical and socio-economic processes that occur in cities, resulting in growth, production of energy, and elimination of waste" [27].

The urban metabolism approach is found in the literature in relation to the three successive ecologies. Newell and Cousins (2015) analyzed the emergence of the industrial ecology, the Marxist ecologies, and the urban ecology as the thought traditions of urban 
metabolism [28]. The industrial ecology accepts Kennedy's definition of urban metabolism. It provides methods such as material flow analysis (MFA), ecological footprint (EF), emergy based accounting (EMA) and more recently life cycle assessment (LCA), to assess the stocks and flows of materials and energy within and beyond the city. Marxist ecologies conceive urban metabolism as a mix of socionatures that produce and reproduce uneven outcomes. Urban ecology theorizes urban metabolism as a complex socio-ecological system providing the theory to investigate urban space's ecological and biophysical properties in nature-society construction (the urban political ecology metabolism).

Similarly, Wachsmuth (2012) interprets the three ecologies as successive periods of urban metabolism [25]. The first one is the human ecology of the Chicago school, which treats the city as an ecosystem analogous to external natural ecosystems, and urban metabolism is conceptualized as a process of social change in the interior of the city. The second one is the industrial ecology, which following Wolman's concept, places society in the city but considers nature merely in a take-and-dispose of scheme-receiving raw inputs and disposing of social wastes. The third era is the urban political ecology. Political ecology is a mixture of the two previous approaches, and the city is conceptualized as an amalgam of socio-natural flows.

We understand an urban place as a "living" organism where interdisciplinary synergies between social-cultural-ecological-technological systems are responsible for the flows and stocks of energy, materials, and information within it and beyond it. Moving the focus beyond mass balance we couple life cycle thinking (LCT) to the multidimensional metabolism of an urban place to consider the direct and indirect impacts of the urban processes. Opposed to the mechanistic vision of cities as mechanical systems that exist in permanent equilibrium to be optimum functional, urban metabolism captures the dynamics, the dialect and flows of all cities' components. The mechanistic approach treats cities as complicated machines that need to be tested, calibrated, and approved through all processes and by analyzed piece by piece. This approach does not allow self-organization and the emergence of spontaneous formation of distinctive spatial and temporal or functional structures from the interaction of many small parts of the city [29]. Therefore, key features of any complex system, such as biological living systems, are not included in the analysis.

We argue that shifting from viewing a city as a system in permanent equilibrium to a complex metabolic system driven from the bottom-up, continually out-of-equilibrium, have strong implications on how we see cities, on our deep understanding on how they function and on their dynamics over time and space, and therefore enable our ability to plan and design better cities. Even though the systems of urban places they are not organic by nature, treating them as such we give a new perspective to the science of cities tracing all nonlinear urban dynamics and relating them to urban problems. Therefore, urban metabolism offers methodologies to support sustainable urban development. We focus on developing a smart and regenerative way to re-plan and re-design the urban metabolisms of the different urban fabrics and profiles of an urban place, making it more natural-human oriented.

\subsection{Urban Places as Smart Complex Systems}

The uncontrolled and rapid urban growth generates various types of challenges as traffic jams, environmental pollution, wasteful energy consumption, safety, security and healthcare issues, and inefficient waste management. Many authors have studied the concept of smart city since the 1990s as a possible remedy to tackle these urban challenges enabling a sustainable and liveable urban future. The smart city concept's lifecycle appears to have passed through three generations. The first generation includes smart cities totally technology driven by private sector technology companies that offer their solutions to improve citizens' quality of life. The second generation was smart cities government-led using information and communications technology (ICT) for smart governance, a decisionsupport tool, and a more resource efficiency management. The last and more recent generation includes smart cities, people-centered or citizen co-creation cities that embrace 
citizen participation through all the decision processes, enabling citizens as sensors, public participation, and volunteer geographic information.

In our conceptual framework, we apply the concept of smart city-user driven to urban systems' metabolism at the urban place-scale, which means that we support all the metabolic processes of an urban place using technology to identify its users' real needs. By applying urban smartness to the complex urban metabolisms' dynamics, we support holistic and sustainable urban growth. Starting the smartization of urban metabolic systems, we provide the most cited definitions of the smart city concept to present and highlight the main features of urban smartness. Thereafter, we relate urban smartness to urban sustainability, and last, we demonstrate how sustainable smart urban metabolism allows us to tackle urban challenges.

Ahvenniemi et al. (2017) state that there are two consecutive main smart city literature strands. The first strand discusses mainly how modern technologies in daily urban systems contribute to a better quality of life, reducing environmental impacts. The second strand adds the human capital to the technical and environmental aspects of a city. A smart city is developed based on "a holistic understanding that smart cities bring together technology, government, and society" [30]. Harrison et al. (2010) define a smart city as an "instrumented, interconnected, and intelligent" city. A smart city is instrumented because it uses various appliances (sensors, meters, surveillance cameras) to capture and integrate real-life data. It is also interconnected because it integrates this acquired information into a platform that allows access to multiple services. Ultimately, a smart city is intelligent because it includes complex analytics, modeling, optimization, and visualization services for better operational decisions [31]. Caragliou et al. (2011), as the most cited work applied to the second part of smart cities literature, define a city as smart "when investments in human and social capital and traditional (transport) and modern (ICT) communication infrastructure fuel sustainable economic growth and high quality of life, with a wise management of natural resources, through participatory governance" [32]. Angelidou (2014) provides a first and clear view on the strategic choices that should be considered when mapping out a smart city strategy using the definition "smart cities are all urban settlements that make a conscious effort to capitalize on the new information and communications technology (ICT) landscape in a strategic way, seeking to achieve prosperity, effectiveness, and competitiveness on multiple socio-economic levels" [33]. Zanella et al. (2014) mention that a smart city aims to make better use of the public resources, increasing the quality of the services offered to the citizens while reducing the public administrations' operational costs [34].

Summarizing the key attributes of the aforementioned smart city definitions, we perceive the smart city concept as the coupling of government, society, and the strategic investing in technology and ICT, resulting in socio-economic growth. A smart city is prosperous, competitive, and effective, establishing prudent management of resources and high-quality user services. We can say that overall, the smart city literature examines the relationship between the concepts of smart city and sustainability [35-37]. After conducting a bibliographic coupling analysis on the infometric cluster of literature that links the smart city concept and sustainability, Peponi and Morgado (2020) highlight that, a city to be truly smart, it must be sustainable as well through all three pillars of sustainability. The three pillars of sustainability; economy, society, and environment has been conceptualized as three successive sustainable development models (Figure 2). In the first model, the three pillars exist independently, as three interlocking rings, where sustainability is placed at their intersection. Human society is separate from the environment implying the reliance on technological fixes to address sustainability issues. The second model of the three nested rings (or Russian doll model) places the economy at the center as a social construct contained within society. The natural environment is the outermost ring since it provides the life support systems for surviving. The last model of the dual nested rings removes the unnecessary separation between human economy and human society. In this way, human society's dependency (including its economic activities) on the environment is recognized 
and taken into account, leading to a more integrating approach to analyze the dimensions of sustainability [38].

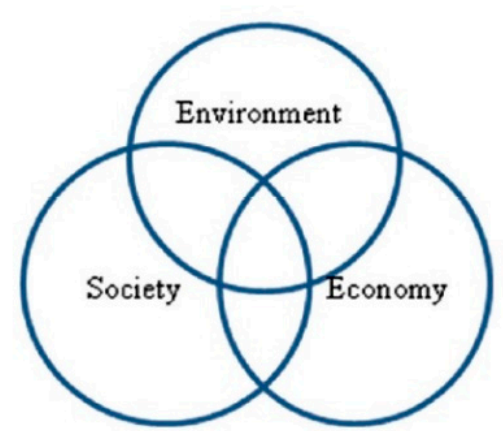

Three interlocking rings

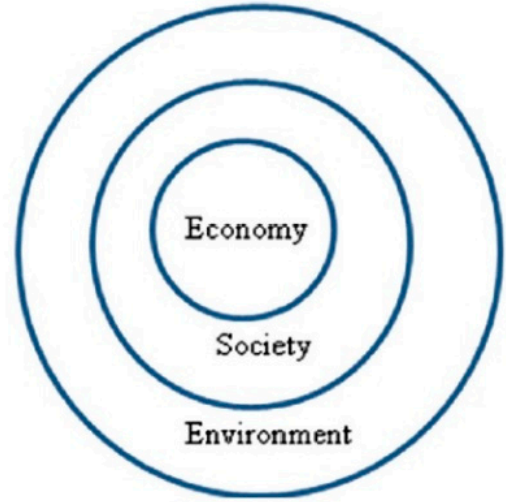

Three nested rings

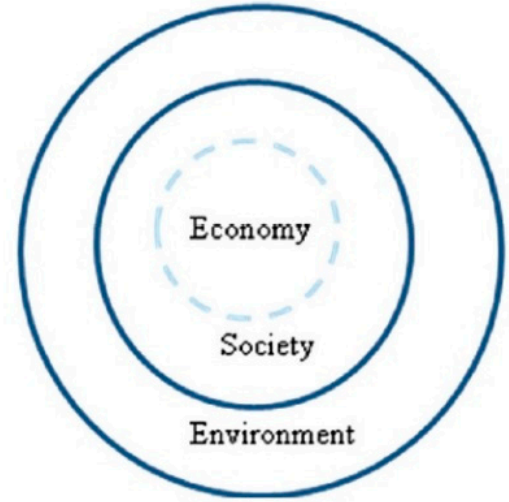

Dual nested rings

Figure 2. Conceptualizations of sustainable development [38].

Designing, planning, and managing the complexity of urban places by adopting the smart-sustainable urban metabolism approach, technology contributes to networking the urban systems, facilitating their metabolic synergies, within the urban place and beyond. Information and communications technology (ICT), and urban Internet of Things (IoT) are applied to the operation of urban infrastructures (buildings, transportation systems, electric systems, etc.), and services (smart traffic monitoring, smart waste management, e-governance, etc.), enhancing their efficiency while promoting social, cultural, economic and environmental sustainability.

\subsection{Urban Places as Regenerative Complex Systems}

In the previous subsections, we demonstrated how the urban metabolism approach integrated with urban smartness allows us to face current urban challenges promoting urban sustainability. As urbanization continues to grow and urban dwellers' affluence to increase, the pressure on local and global rural areas increases, resulting in increased resource intensity, waste production, and environmental pollution. The so-far linear urban metabolism of "take, make, consume, and dispose" could be reformed to circular to eliminate negative implications of wasteful urbanization. This metabolic circularity in urban systems protects the environment and natural resources not only by sustaining them but by regenerating them instead. In this subsection, we demonstrate how the regenerative design of urban metabolic processes tackles urban challenges overpassing the limitations of other circular metabolism concepts, ensuring sustainable growth for future generations.

Lyle (1996) in 1996, first expressed the idea to replace the linear flows of a city with cyclical in the field of development and design. According to Lyle this change to circular flows at sources, consumption centers and sinks, it is related to the rebirth of life itself, and therefore to the hope for the future [39]. (Re)-designing urban metabolisms under circularity is the basis of different schools of thought such as regenerative design, looped, and performance economy, cradle to cradle (C2C), industrial ecology, close supply chain (or closed-loop supply), biomimicry, blue economy. These aforesaid concepts have inspired the circular economy (CE) a new business model for a sustainable economy and a healthy environment $[40,41]$. Although CE is still a non-consolidated concept, difficult to describe and comprising diverse areas, such as sustainable production-consumption systems; closedloop supply chains; and product-service systems [42]. The Ellen Macarthur Foundation in 2015 put forward a definition of CE as "one that is restorative and regenerative by design and aims to keep products, components, and materials at their highest utility and value at all times, distinguishing between technical and biological cycles" [43] (Figure 3). 


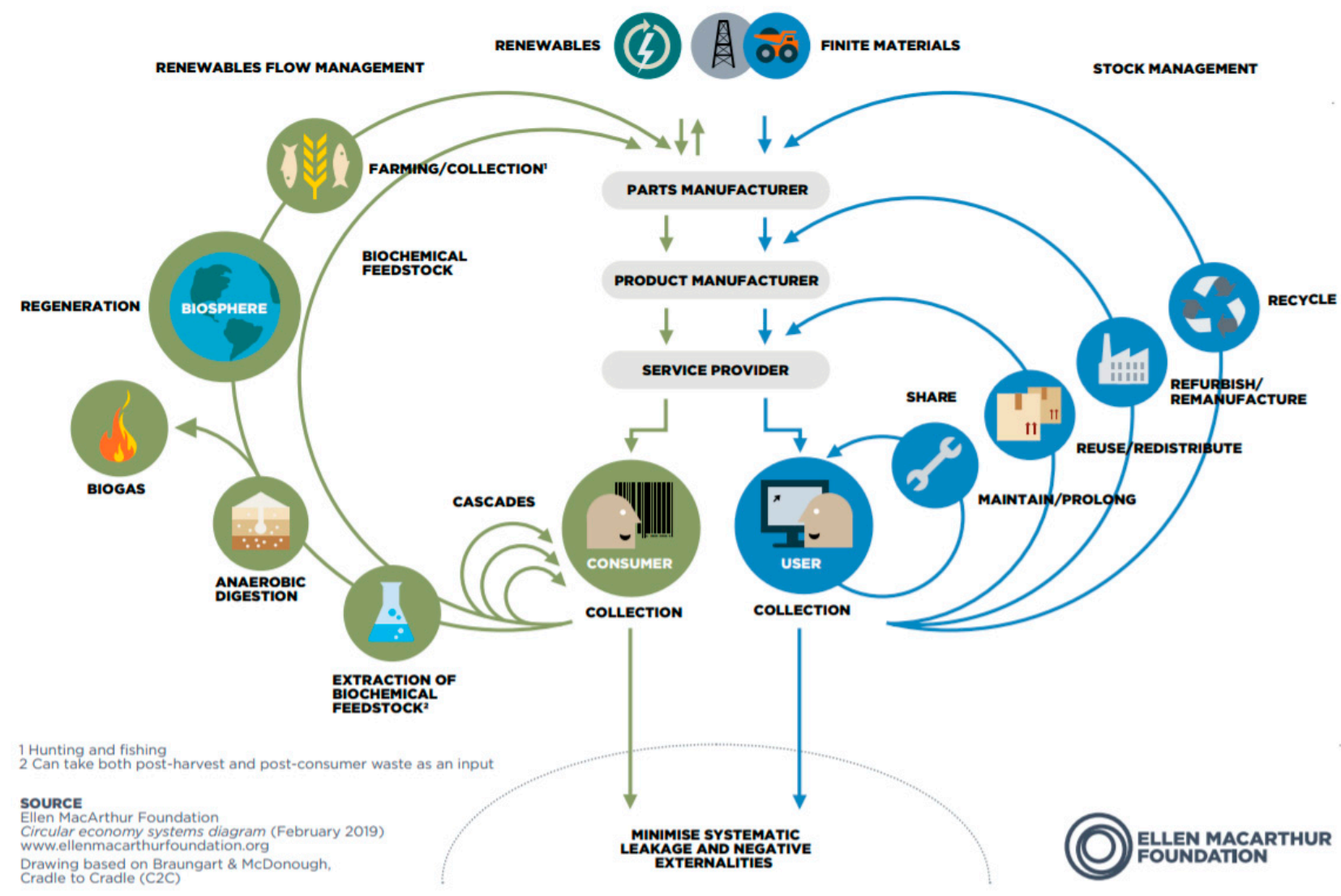

Figure 3. Butterfly diagram of systematic circular economy.

Although the concepts of restoration and regeneration appear of high importance and used widely within CE, as Morseletto, in his work in 2020, affirms, "are rarely denied or explained". Notably, the concept of regeneration appears as "a symbolic/evocative term with little practical application in the context of circular systems except in the case of certain agricultural practices. Until new developments intervene, regeneration does not seem to apply to the economy as a whole, and because of this, it might be abandoned as a guiding principle of the circular economy" [44]. In the same line, Geisendorf and Pietrulla (2018), after reviewing the CE concept, summarize that CE needs to be a regenerative system, but instead, most of the studies have been focused on waste management using a limited interpretation of the 3Rs principles (reduce-reuse-recycle) although these principles propose wider options [41]. Faraud (2017) as well points out that CE appears to be limited mainly under the umbrella of waste, and by narrowing the focus on flow circularity leads to a different type of linear analysis [45,46]. Naboni et al. (2019) advocate that regenerative design, even that it goes far from just the limitation of the environmental impact of the built environment to climate change adaptation and improvement of human health, its implementations to urban scale are rare [47].

Scholars agree that the circularity of the metabolic processes need a regenerative design to ensure that urban growth can be sustained in longer terms. Nevertheless, we empirically know that there is still a long way to go as there is a lack of specific metrics, indicators tools, and methodological workflows capable of putting in practice regenerative design concepts.

We advocate that to create an urban place as regenerative complex system, we need to focus on the holistic regenerative design of the metabolisms of the social, cultural, technological, and ecological systems of urban places. A part of regenerative design studies supports that understanding the relationships between ecosystems and human society is the key to truly regenerative design, ensuring maximum wellbeing for both [48-50]. By 
treating urban systems as complex open ecosystems, incorporating ecosystem processes and services, we plan and design their metabolic processes in a holistic and regenerative way, overpassing circularity limitations as system boundary limits (see limits, challenges, and CE barriers in $[51,52])$. Through this regenerative paradigm, the relationships between urban places and the natural systems that they depended on are enhanced and restored, reaching the goals of the three dimensions of sustainability.

\section{Smart and Regenerative Urban Places (SRUP): A new Conceptual Framework}

In the first part of our conceptual analysis we demonstrated that urban places to be smart, they need to be sustainable simultaneously through all three pillars of sustainability. As well as, regenerative designed urban places are truly sustainable in longer terms through restoration, revitalization, and improvement of their environment, people, and communities. Both smart city and urban regeneration concepts have been proposed and applied by scholars attempting to achieve sustainable urban growth and, therefore, to equip cities to meet modern urbanization challenges. In this second part of our conceptual analysis, we synthesize the conceptual framework of Smart and Regenerative Urban Places (SRUP), interconnecting the two aforementioned concepts under the broader framework of sustainability. We propose SRUP conceptual framework as a response to the limits of urban smartness and urban regeneration approach to achieve sustainability unilaterally. We conceptualize smart and regenerative urban places as the intersection of two rings (smart, regenerative concept) depicted in Figure 3. These rings appear with the same diameter since we treat the concepts as having equal importance, but without being homocentric because they are not the same concept. We place the sustainability concept in the intersection of smart and regenerative rings as being their interconnection factor. Sustainability does not cover the entire interconnection area since, in our understanding, smart and regenerative urban places are not just sustainable. This way, we built a cat-eye shaped diagram to depict our novel integrated and holistic conceptual framework at urban places scale, as shown in Figure 4 .

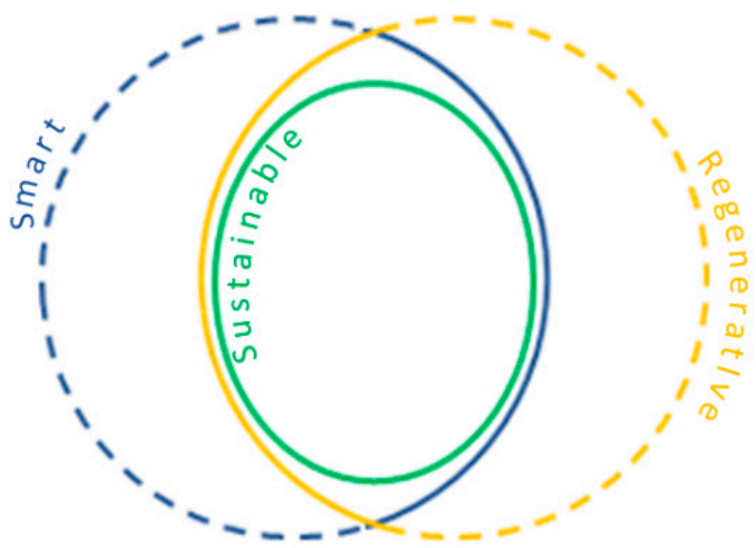

Figure 4. Cat-eye diagram of smart and sustainable urban places (blue for smart + yellow for regenerative $=$ green for sustainable).

In Table 1, we summarize the aspects of our integrated conceptual framework. The table is designed to provide information by reading its columns vertically starting from the top left corner. In the first column, we see the concepts that constitute our novel framework SRUP (see previous sections). The second column mentions the spatial and temporal scale at which the framework is set. In the third column, we found the main dimensions of urban places to be measured and assessed, in the fourth column the stakeholders involved, and the principles of SRUP we adopt are summarized in the fifth column. In this way, specific characteristics are given to urban systems, as shown in the table's sixth column under SRUP framework. Examples of urban metabolic processes corresponding to main dimensions 
under the implementation of SRUP are presented in the table's seventh column. The table continues with the overall goals we attempt to achieve by applying this conceptual framework.

Table 1. An integrated conceptual framework for smart and regenerative urban places as complex systems (SRUP).

\begin{tabular}{|c|c|c|c|}
\hline Concepts & Scale & Dimensions & Stakeholders \\
\hline Smart city & $\begin{array}{l}\text { Spatial: } \\
\text { Urban Place }\end{array}$ & Social & Local government \\
\hline \multirow[t]{3}{*}{$\begin{array}{l}\text { Regenerative urban planning } \\
\text { and design }\end{array}$} & $\begin{array}{c}\text { Temporal: } \\
\text { Coevolutionary } \\
\text { existence of relationship }\end{array}$ & Cultural & Local communities \\
\hline & & Technological & NGO's \\
\hline & & Ecological & Public and private companies \\
\hline Principles & Characteristics & $\begin{array}{l}\text { Processes } \\
\text { (examples) }\end{array}$ & Goals \\
\hline Holistic thinking & Open interdependent systems & Amenity services & Safety and Security \\
\hline Systematic thinking & Complex systems & $\begin{array}{c}\text { Wastewater recycling and } \\
\text { reuse }\end{array}$ & Quality of life \\
\hline $\begin{array}{l}\text { Real-time data-driven } \\
\text { approach }\end{array}$ & Open access to public data & $\begin{array}{c}\text { Recycling of } \\
\text { non-biodegradable wastes }\end{array}$ & Liveability \\
\hline $\begin{array}{l}\text { Urban ecology- Metabolic } \\
\text { approach }\end{array}$ & User-centric approach & $\begin{array}{c}\text { Cycling of biodegradable } \\
\text { wastes }\end{array}$ & Attractiveness \\
\hline $\begin{array}{c}\text { Smartizating and } \\
\text { Regenerating the exploitation } \\
\text { of natural resources, } \\
\text { human-social capital, } \\
\text { economy, mobility, and } \\
\text { governance }\end{array}$ & Living systems & $\begin{array}{l}\text { Dashboard showing economic, } \\
\text { social, and environmental } \\
\text { performance }\end{array}$ & $\begin{array}{l}\text { Competitiveness \& } \\
\text { effectiveness }\end{array}$ \\
\hline 3D sustainability & Mimicking ecosystems & $\begin{array}{l}\text { Ecosystem functions and } \\
\text { services }\end{array}$ & Creativity \\
\hline & Circular metabolisms & & Economic growth \\
\hline & Social equity & & Zero-Waste \\
\hline & Environmental justice & & \\
\hline
\end{tabular}

Adopting a systematic thinking approach and accepting the organic analogy of urban places as living organisms, we plan and design the metabolic processes of the social, cultural, technological, and ecological systems of urban places in a smart and regenerative way. Considering these systems as open and interdependent in permanent interaction within and beyond the boundaries of an urban place, we perceive urban places' planning and design as circular, ongoing [8], and co-evolutionary [53]. Conceptualizing smart and regenerative urban places, we face the complexity of the urban systems holistically by applying advanced technologies and real-time data-driven approaches in conjunction with urban ecology principles.

From the urban ecological point of view, understanding and mimicking organisms, their behaviors, and whole ecosystems (including their functions and services), serves as a paradigm of planning and designing an urban system able to return to the thriving state before exposed to hazards. Zari (2012) integrate ecosystem services into the built environment and identify the six most suitable ecosystem services for regenerative design (Table A1) [54]. Accordingly, an urban place is designed to provide habitat for species, purify the air, water, and soil, and regulate the climate mitigating greenhouse emissions. Moreover, we argue that a regenerative designed urban place contributes to soil formation and fertility through 
careful cycling of biodegradable waste and recycling non-biodegradable wastes, produces renewable energy, and supports rainwater collection wastewater recycling and reuse.

Nowadays, an abundance of technologies transforms almost everything into a data source. Using these technologies in urban lifeline systems allows us to have access to a huge amount of data, from a variety of sources, at an unprecedented rate and with veracity, in other words, big data. Therefore, big data, along with advanced algorithms for spatial data analysis and the access to high computing power coupled with ecosystem services analysis, enable us to manage the complexity of urban living more efficiently. Therefore, we cannot have urban solutions of 'one size fits all'. Different neighborhoods show different systems behaviors and therefore need different solutions. Comparing high-density residential old neighborhoods with newly developed neighborhoods, we can see the differences and the need to develop and apply tailored solutions. In the first case, the buildings are old located in medieval parts of the cities and maybe on high slopes. They are built based on different transport systems, having narrow streets and sidewalks. Most of these urban places face challenges regarding; domestic garbage collection, building energy efficiency, accessibility, lack of green public spaces, citizens vulnerability to natural hazard as heat, cold waves, floods, and contagious diseases, among others. The new neighborhoods in the new part of the city have new energy-efficient buildings and an underground waste collection system. They are planned to have broad sidewalks with arrays of trees and green spaces promoting healthier lifestyles. Social facilities are located within walking distance promoting environmentally friendly mobility. Our point is that we can provide different actions and measures fitted to different places at a low-scale level to solve their unique problems with knowledge-based actions due to Big data and ecosystem analysis.

Far from just limiting the negative environmental impacts of urbanization and a zero waste-oriented approach, the SRUP design focuses on positive environmental benefits. It fosters health and, at the same time, improves the quality of life of the inhabitants and the companies, tourists, researchers, entrepreneurs, and all the urban tissue of the urban places. By learning from ecosystem processes, we apply this knowledge to smartizating and regenerating the exploitation of natural resources, the human and social capital, the economy, mobility, governance, and how they interact with each other. Therefore, we are able to design safe and secure, attractive and liveable, and more creative urban places.

ICT-based urban monitoring and surveillance systems embedded with artificial intelligence, business intelligence, machine learning algorithms, and image processing techniques to manage and analyze real-time data support urban places' security and safety [55]. Along with regenerative-based solutions, it powers our ability to conduct urban risk assessment specifying potential hazards and vulnerabilities, seeking to strengthen the urban place's resilience, security, and safety related to natural and socio-economic hazards.

An urban place that grows smarter and regenerative is attractive for all to live and work. Smart and regenerative urban design and planning limits the use of resources, it tackles bureaucratic issues by offering high quality of services, and it promotes a usercentric approach by engaging citizens in the city's functioning. At the same time, it enables economic growth to attract investors and businesses due to the quality and efficiency of the provided infrastructure that facilitates commerce and reduces friction. In addition to this, while fully equipped, smart cities should provide a dashboard showing economic, social, and environmental performance. Jointly, it contributes to leverage economic ICT-based companies and startups, avoiding brain drain and keeping the young workforce (talent) from leaving.

Recognizing the affective attachment that individuals have with a place, we aim to plan and design in a smart and regenerative way liveable urban places enhancing the communities' quality of life and individual wellbeing. This affective attachment is built through the experience of the individuals. It is measured by the degree of their overall satisfaction and wish for residential stability in the place [56]. To strengthen this affective bond of individuals with the place, we enhance the quality of the environment (residential and natural) of the place according to users' needs, the place identity [57], and territoriality. 
Building smart, blue and green infrastructure, we focus on urban happiness and health contributing to the place's overall liveability.

In line with Sepe (2014), the creativity of an urban place is related to the identity capital and innovation of the place [58]. Enhancing and developing the unique characteristics of a place through cultural, artistic productions, research, technological, and ecological smart regeneration, we strengthen their competitiveness and effectiveness. Therefore, combining all the characteristics of smart and regenerative urban places mentioned above, urban places are able to face long-standing urban challenges related to environmental justice, social equity, poverty, emergency management, provision and consumption of amenity services, urban ecosystems under pressure, efficient use of energy, renewable energy development, infrastructure provision, sustainable transport, delivery of life support services including water, sanitation, education, health.

Close collaboration with key stakeholders is required to implement this conceptual framework and extend the knowledge and practical evidence from it. Stakeholders can be local and regional government, public-private companies operating in the field, local communities, and private companies, and NGO's. Equally important is the need to develop legislation that allows synergies (economic and technical) between all the systems of an urban place. As well as activities that shorten the distance and, at the same time, strengthen the link between academia and stakeholders that can implement the measures and implement new policies, is critical.

\section{Smart and Regenerative Urban Places: Main Challenges and Discussion}

In this section we discuss the limitations/challenges of urban smartness and regenerative design to sustainable urban growth in perspective of previous studies, and how we address these challenges though an integrating conceptual framework under urban metabolism approach.

One of the critical processes included in the proposed conceptual framework coming from the regenerative design subconcept, is the ecosystem service analysis. As Zari (2012) points out, the analysis of ecosystem services is a promising but long-term approach to meet sustainability goals [54]. However, simultaneously, it increases the potential for accuracy while creating a measurable design based on the urban place's physical reality rather than some anthropogenic activity or political trend. Therefore, integrating the ecosystem analysis with the smart city concept, we conceptualize new digital services with an overall goal to improve the quality of life and work of citizens and companies.

Despite all the benefits coming from this conceptual integration, we identify a few fundamental challenges. As mentioned in the previous section, a large amount of spatial data is obtained from various sources constantly within urban places. Therefore, besides having access to a large volume of data, it is crucial to assess meaningful data that we can analyze and turn into knowledge. Maintaining and improving the quality of this data is fundamental mainly for two reasons. Firstly, the overall quality of a model (especially an analytical model) depends not just on the policy guidelines and recommendations but also on the data quality. Secondly, the overall realism of an operational research project relies on data quality as well. In synthesis, data curation is critical for the quality and realism of project deliveries, in general. Efficient data storage and processing facilities, as well as computational intelligence algorithms, are required to extract valuable information from the datasets to plan, design, and manage smart and regenerative urban places. The IoT and the cloud computing services available nowadays are possible ways to overcome this challenge [59].

A further challenge related to data privacy, protection, and sharing is how to build trust that the use of data for smartness and efficiency is not putting at risk individual privacy and personal control in data collection and management and city's sovereignty. In smart and regenerative design, data circulates openly accessibly through the metabolic processes of an urban place with the responsibility of companies and governments. Revealing the full value of data as a common good and engaging citizens' participation in the design, we encounter this ethical challenge of smart city concept [60]. The citizens have an empowering 
role in the design process of an urban place. Through collaboration with governments, citizens are involved in the decision-making process identifying priorities, strategies, and goals regarding matters of public relevancy. Citizens are crucial stakeholders to generate valuable ideas to meet social needs and, at the same time ICT users [61].

Another critical issue regarding the human capital dimension is focused on consumer behavior. Callaud and Laperche (2016) mention that the mass consumption model in the post-war era promotes consumer behavior based on high rates of household consumer equipment and highly equipped cars [40]. Adding to this trend, companies promote behavior based on equipment replacement, building products with low-quality materials, and making it hard for consumers to find inexpensive spare parts. Moreover, by advertising the idea of products fast renewing to maintain the benefit of last technological developments, the consumption increases. With planning and designing smart and regenerative urban places, the essential scope is saving, restoring, and regenerating resources. Therefore, it is safe to say that consumption behavior needs further evolution towards a smart and regenerative consumer's behavior.

The aforesaid consumption behavior is closely related to the growing challenge of e-waste. The increased demand of electronic equipment either for household use or at city level, results in shortages of raw materials necessary for its production. Through urban mining processes, rare metals coming from electronic and electrical waste are reclaimed and reused to produce new equipment to support the needs of smart city concept. In many cases, where urban mining occurs informally, it results in serious health hazards, security risks, and environmental pollution due to the toxic substance realized through reclaiming processes. Applying our proposed framework of smart and regenerative urban planning and design, we can face this e-waste challenge, focusing not only on recycle but avoiding e-waste disposal to landfill and incineration sites at first place via circular metabolisms. Life cycle assessment coupled with urban metabolism supports the smart and regenerative e-waste management practices estimating the environmental impact of the e-waste treatment performing end-of-life scenarios.

A topic of significance under discussion is the cost-effectiveness of adopting smart and regenerative places. Transforming an urban place into a smart and regenerative requires time and money to invest in ICT infrastructure, to build an integrated master planning of control methodologies of big data [59] and circular metabolisms. In addition, it is difficult to monetize the benefits of this transformation especially benefits from ecosystem services and the positive socioeconomic impacts. Considering these, local governments and decision-makers, and urban planners need to develop business models that could attract public funding and private financing to make this transformation of urban places viable and financeable. Moreover, they need to engage all urban agents so the concept of public place as a place of all and for all, be assimilated and leverage the sense of responsibility across the community. The holistic design of an urban model that we suggest involves all stakeholders, it is based on knowledge adopting good practice and guidelines, and therefore, it contributes to further cost savings. For example, through smart lighting, which uses renewable energy, we save energy costs. Using smart technologies in administrative procedures manpower costs can be saved as well as savings in public funds related to urban security and city maintenance, cost reduction for maintenance and waste collection and treatment services are also.

\section{Conclusions}

The world as we used to know it is going through significant changes. Urban areas are growing and expanding, covering more space than rural areas, increasing resources consumption, energy demand, and generate waste. This unbalanced relationship between urban areas and nature leads to social, economic, and environmental challenges that urban areas, in all their complexity, are critical to face and ensure sustainability in urban growth Based on a literature review, we verified that the smart city concept is related to urban sustainability, and the regenerative design studies embrace sustainability to maintain a 
healthy state of urban systems and move one step further by allowing the urban systems to flourish and evolve. We also verified that the concepts of urban smartness and urban regeneration had been studied separately in the pathway to reach sustainability. In this paper, we have proved that we cannot fully understand the complexity of urban areas without a holistic and integrative systematic approach. Therefore, having demonstrated the importance and the role of each concept of our interest, we integrated them via sustainability principles, highlighting the symbiotic and mutually beneficial interconnection. We conceptualized the novel framework of smart and regenerative urban places (SRUP) under the urban metabolism approach to encounter the current challenges of urban complexity, supporting the idea that an urban place to be truly regenerative needs to be smart and vice versa.

We perceive the relationship between the urban systems (social-cultural-ecologicaltechnological) as open and co-evolutionary at the urban place scale. Focusing on urban places, besides their spatial and human aspects, we emphasize the sense of safety, security, and identity. In other words, we reflect the attachment bond that inhabitants have with the place they live in as a mix of cultural and physical features that make this place unique, authentic, offering a sense of security and safety to its inhabitants. Giving a co-evolutionary context in our framework, we highlight the need for continually maintaining and improving, in an integrating way, the relationship between the human and natural capital. Our holistic framework goes beyond sustainability, transforming urban places into truly smart and regenerative by combining advanced technologies and ecological principles. In this way, we re-design the urban place's metabolisms so as to be attractive and liveable, competitive and effective, and innovative with a higher goal to restore the health of natural resources recognizing the value of ecosystem services and the cost of their loss.

To implement this innovative conceptual framework requires investments and collaborations between businesses and the government engaging public participation in the process. Complex systems, such as urban areas' dynamics, are full of uncertainty and therefore demanding for an integrative systems approach, and at the same time a holistic perspective of the whole instead of focusing on single parts. All actors should be engaged with the urban place dynamics, building a more systemic worldview, and adopting a more participatory attitude in the decision-making process. All in all, combining all the characteristics of smart and regenerative urban places mentioned above, urban places are able to face long-standing urban challenges, e.g., environmental justice, social equity, poverty, emergency management, provision and consumption of amenity services, urban ecosystems under pressure, etc.

As the main problems to our model implementation, we have noticed that there is a lack of meaningful eco-geo-urban data at a high-resolution scale, produced systematically in time and space, as well as tools to analyze them and build evidence-based knowledge. Our next step is to evaluate the smart and regenerative performance in all the dimensions of selected urban places under study. Initially, we will define a set of variables representing the principles and characteristics of a smart and regenerative urban place. Using these variable and advanced methods, we will measure and assess the study areas' metabolic processes. A protocol agreement, regarding access to data, with a local stakeholder, has already been established and signed.

Author Contributions: Conceptualization, A.P.; investigation, A.P.; writing-original draft preparation, A.P. and P.M.; writing - review and editing, A.P and P.M. All authors have read and agreed to the published version of the manuscript.

Funding: The APC was funded by FCT (UIDP/00295/2020) through CEG budget.

Informed Consent Statement: Not applicable.

Data Availability Statement: Data sharing not applicable.

Conflicts of Interest: The authors declare no conflict of interest. 
Appendix A

Table A1. Ecosystem services for the built environment [54]

\begin{tabular}{|c|c|c|c|c|c|}
\hline \multirow[b]{2}{*}{ Ecosystem Service } & \multicolumn{3}{|c|}{ Ranking Criteria } & \multirow[b]{2}{*}{$\begin{array}{c}\text { Examples of Existing Design } \\
\text { Methods that Could } \\
\text { Be Potentially Be Used }\end{array}$} & \multirow[b]{2}{*}{ Positive Environmental Implications } \\
\hline & $\begin{array}{l}\text { Applicability to } \\
\text { the Built } \\
\text { Environment }\end{array}$ & $\begin{array}{l}\text { Ecological } \\
\text { Significance }\end{array}$ & $\begin{array}{c}\text { Negative } \\
\text { Environmental Impact } \\
\text { Caused by the Built } \\
\text { Environment }\end{array}$ & & \\
\hline \multicolumn{6}{|l|}{ Supporting services } \\
\hline $\begin{array}{l}\text { 1. Habitat provision (including: } \\
\text { provision of genetic information; } \\
\text { biological; fixation of solar } \\
\text { energy; and species maintenance) }\end{array}$ & Medium & High & High at a local scale & $\begin{array}{l}\text { Revegetation; preservation of existing } \\
\text { flora and fauna; urban wildlife } \\
\text { sanctuaries; living walls; } \\
\text { urban forests; green roofs and facades; } \\
\text { wildlife corridors; green belts }\end{array}$ & $\begin{array}{l}\text { Increased biodiversity; reduction of the } \\
\text { urban heat island effect; sequestration of } \\
\text { carbon; increased air, water and soil quality; } \\
\text { remediation of some forms of water, air and } \\
\text { soil pollution; possible protection from wind } \\
\text { or wave surges; more adaptable ecosystems } \\
\text { as the climate changes; } \\
\text { reduction of storm water peak flows }\end{array}$ \\
\hline $\begin{array}{l}\text { 2. Nutrient cycling (including: } \\
\text { decomposition; soil building; } \\
\text { and the provision of raw } \\
\text { materials) }\end{array}$ & Medium & High & $\begin{array}{l}\text { High at a regional scale/ } \\
\text { global scale }\end{array}$ & $\begin{array}{l}\text { Recycling and reuse techniques; } \\
\text { cradle-to-cradle design; composting } \\
\text { techniques; design for } \\
\text { deconstruction; landfill mining; } \\
\text { industrial ecology }\end{array}$ & $\begin{array}{c}\text { Reduction of waste; reduced need for } \\
\text { mining/ } \\
\text { growing/production/transportation of } \\
\text { materials } \\
\text { and energy leading to reduction in } \\
\text { greenhouse } \\
\text { gas (GHG) emissions, waste and ecosystem } \\
\text { disturbance; decreased use of energy; } \\
\text { increased } \\
\text { health of ecosystems and humans }\end{array}$ \\
\hline \multicolumn{6}{|l|}{ Regulation services } \\
\hline 3. Purification & High & High & $\begin{array}{l}\text { High at a local/regional } \\
\text { scale }\end{array}$ & $\begin{array}{l}\text { Living machines; phyto-remediation } \\
\text { and bioremediation; filtration } \\
\text { techniques; green roofs and facades; } \\
\text { urban forests; constructed wetlands; } \\
\text { composting techniques }\end{array}$ & $\begin{array}{l}\text { Increased health of living organisms; } \\
\text { increased terrestrial and marine } \\
\text { productivity; reduction of air and water } \\
\text { pollution; eutrophication reduction; } \\
\text { remediation of polluted sites; reduced ozone } \\
\text { damaging gas and GHG emissions }\end{array}$ \\
\hline
\end{tabular}


Table A1. Cont.

\begin{tabular}{|c|c|c|c|c|c|}
\hline \multirow[b]{2}{*}{ Ecosystem Service } & \multicolumn{3}{|c|}{ Ranking Criteria } & \multirow[b]{2}{*}{$\begin{array}{c}\text { Examples of Existing Design } \\
\text { Methods that Could } \\
\text { Be Potentially Be Used }\end{array}$} & \multirow[b]{2}{*}{ Positive Environmental Implications } \\
\hline & $\begin{array}{l}\text { Applicability to } \\
\text { the Built } \\
\text { Environment }\end{array}$ & $\begin{array}{c}\text { Ecological } \\
\text { Significance }\end{array}$ & $\begin{array}{c}\text { Negative } \\
\text { Environmental Impact } \\
\text { Caused by the Built } \\
\text { Environment }\end{array}$ & & \\
\hline 4. Climate regulation & High & High & High at a global scale & $\begin{array}{l}\text { Storage of carbon in building structure; } \\
\text { revegetation; design to enable } \\
\text { behaviour change in energy use; } \\
\text { renewable energy generation; passive } \\
\text { solar design; non-high thermal mass } \\
\text { infrastructure and landscaping; design } \\
\text { to reduce reliance on fossil fuels }\end{array}$ & $\begin{array}{c}\text { Mitigation of the causes of climate change; } \\
\text { more } \\
\text { adaptable communities; mitigation of the } \\
\text { urban } \\
\text { heat island effect; improved health of living } \\
\text { organisms }\end{array}$ \\
\hline \multicolumn{6}{|l|}{ Provisioning services } \\
\hline $\begin{array}{l}\text { 5. Provision of fuel/energy } \\
\text { for human consumption }\end{array}$ & High & Medium & High at a global scale & $\begin{array}{l}\text { Design for renewable energy } \\
\text { generation; cogeneration methods; } \\
\text { design to enable behaviour change to } \\
\text { reduce energy use; industrial/ } \\
\text { construction ecology }\end{array}$ & $\begin{array}{l}\text { Reduced transport and energy generation } \\
\text { related GHG emissions; more self-reliant } \\
\text { and therefore robust urban environments; } \\
\text { reduction of air, water and soil pollution; } \\
\text { reduction of mining and drilling impacts }\end{array}$ \\
\hline
\end{tabular}




\section{References}

1. Seto, K.C.; Sánchez-Rodríguez, R.; Fragkias, M. The new geography of contemporary urbanization and the environment. Annu. Rev. Environ. Resour. 2010, 35, 167-194. [CrossRef]

2. Webb, R.; Bai, X.; Smith, M.S.; Costanza, R.; Griggs, D.; Moglia, M.; Neuman, M.; Ao, P.N.; Newton, P.; Norman, B.; et al. Sustainable urban systems: Co-design and framing for transformation. Ambio 2018, 47, 57-77. [CrossRef] [PubMed]

3. Kulkarni, K. Smart City as System of Systems: Subject of study-Vertical Farming and Autonomous Driving in Smart city. INCOSE Int. Symp. 2019, 29, 505-517. [CrossRef]

4. Jacobs, J. The Death and Life of Great American Cities; Random House: New York, NY, USA, 1961.

5. Montgomery, C. Happy City: Transforming our Lives through Urban Design; Penguin Books: London, UK, 2013; ISBN 978-0-141-04754-6.

6. Batty, M. Inventing Future Cities; MIT Press: London, UK, 2018; ISBN 9780262038959.

7. Tuan, Y.-F. Space and Place: The Perspective of Experience; University of Minnesota Press: Minneapolis, MN, USA, 1977; ISBN 978-08166-38772.

8. Mang, P.; Reed, B. Designing from place: A regenerative framework and methodology. Build. Res. Inf. 2012, 40, 23-38. [CrossRef]

9. AbouKorin, A.A. Spatial analysis of the urban system in the Nile Valley of Egypt. Ain Shams Eng. J. 2018, 9, 1819-1829. [CrossRef]

10. Chroley, R.; Haggett, P. Models in Geography; Methuen \& Co., Ltd.: London, UK, 1967.

11. Batty, M.; Axhausen, K.; Fosca, G. UCL Centre for advanced spatial analysis papers. Analysis 2008, 44, 0-18. [CrossRef]

12. Batty, M.; Marshall, S. The origins of complexity theory in cities and planning. In Complexity Theories of Cities Have Come of Age, An Overview with Implications to Urban Planning and Design; Springer: Berlin, Germany, 2012 ; pp. 21-45.

13. Favis-Mortlock, D. Non-Linear dynamics, self-organization and cellular automata models. In Environmental Modelling: Finding Simplicity in Complexity; Wainwright, J., Mulligan, M., Eds.; John Wiley \& Sons, Inc.: Hoboken, NJ, USA, 2013 ; pp. 45-68.

14. Wilson, A.G. Ecological and urban systems models: Some explorations of similarities in the context of complexity theory. Environ. Plan. A 2006, 38, 633-646. [CrossRef]

15. Fisher, D.N.F.; Ruitt, J.N.P. Insights from the study of complex systems for the ecology and evolution of animal populations. Curr. Zool. 2020, 66, 1-14. [CrossRef]

16. Patorniti, N.P.; Stevens, N.J.; Salmon, P.M. A sociotechnical systems approach to understand complex urban systems: A global transdisciplinary perspective. Hum. Factors Ergon. Manuf. 2018, 28, 281-296. [CrossRef]

17. Yu, G.; Li, M.; Xu, L.; Tu, Z.; Yu, Q.; Yang, D.; Xie, X.; Yang, Y. A theoretical framework of urban systems and their evolution: The GUSE theory and its simulation test. Sustain. Cities Soc. 2018, 41, 792-801. [CrossRef]

18. Bretagnolle, A.; Daudé, É.; Pumain, D. From theory to modelling: Urban systems as complex systems; La complexité dans les systèmes urbains: De la théorie au modèle. Cybergeo 2006, 335, 1-26. [CrossRef]

19. Basu, S.; Bale, C.S.E.; Wehnert, T.; Topp, K. A complexity approach to defining urban energy systems. Cities 2019, 95 , 102358. [CrossRef]

20. Graham, S.; Marvin, S. Splintering Urbanism. Networked Infrastructures, Technological Mobilities and the Urban Condition; Routledge: London, UK, 2001.

21. Peponi, A.; Morgado, P. Smart and regenerative urban growth: A literature network analysis. Int. J. Environ. Res. Public Health 2020, 17, 2463. [CrossRef] [PubMed]

22. Jabareen, Y. Building a conceptual framework: Philosophy, definitions, and procedure. Int. J. Qual. Methods 2009, 8, 49-62. [CrossRef]

23. Foster, J.B. Metabolism of nature and society. In Marx's Ecology: Materialism and Nature; Monthly Review Press: NY, USA, 2000; pp. 141-177.

24. Weiland, U.; Richter, M. (Eds.) Urban ecology-brief history and present challenges. In Applied Urban Ecology: A Global Framework, 1st ed.; Blackwell Publishing Ltd.: Oxford, UK, 2012.

25. Wachsmuth, D. Three ecologies: Urban metabolism and the society-nature opposition. Sociol. Q. 2012, 53, 506-523. [CrossRef]

26. Wolman, A. The metabolism of cities. Sci Am. 1965, 213, 179-190. [CrossRef]

27. Kennedy, C.; Pincetl, S.; Bunje, P. The study of urban metabolism and its applications to urban planning and design. Environ. Pollut. 2011, 159, 1965-1973. [CrossRef]

28. Newell, J.P.; Cousins, J.J. The boundaries of urban metabolism: Towards a political-industrial ecology. Prog. Hum. Geogr. 2015, 39, 702-728. [CrossRef]

29. Portugali, J. Complexity Theories of Cities Have Come of Age. An Overview with Implication to Urban Planning and Design; Springer: Berlin, Germany, 2012

30. Ahvenniemi, H.; Huovila, A.; Pinto-Seppä, I.; Airaksinen, M. What are the differences between sustainable and smart cities? Cities 2017, 60, 234-245. [CrossRef]

31. Harrison, C.; Eckman, B.; Hamilton, R.; Hartswick, P.; Kalagnanam, J.; Paraszczak, J.; Williams, P. Foundations for smarter cities. IBM J. Res. Dev. 2010, 54, 1-16. [CrossRef]

32. Caragliu, A.; Del Bo, C.; Nijkamp, P. Smart cities in Europe. J. Urban. Technol. 2011, 18, 65-82. [CrossRef]

33. Angelidou, M. Smart city policies: A spatial approach. Cities 2014, 41, S3-S11. [CrossRef]

34. Zanella, A.; Bui, N.; Castellani, A.; Vangelista, L.; Zorzi, M. Internet of things for smart cities. IEEE Internet Things J. 2014, 1, 22-32. [CrossRef]

35. Bibri, S.E.; Krogstie, J. Smart sustainable cities of the future: An extensive interdisciplinary literature review. Sustain. Cities Soc. 2017, 31, 183-212. [CrossRef] 
36. Macke, J.; Casagrande, R.M.; Sarate, J.A.R.; Silva, K.A. Smart city and quality of life: Citizens' perception in a Brazilian case study. J. Clean. Prod. 2018, 182, 717-726. [CrossRef]

37. Yigitcanlar, T.; Kamruzzaman, M.; Foth, M.; Sabatini-Marques, J.; da Costa, E.; Ioppolo, G. Can cities become smart without being sustainable? A systematic review of the literature. Sustain. Cities Soc. 2019, 45, 348-365. [CrossRef]

38. Lombardi, D.R.; Porter, L.; Barber, A.; Rogers, C.D.F. Conceptualising sustainability in UK urban regeneration: A discursive formation. Urban. Stud. 2011, 48, 273-296. [CrossRef]

39. Thomson, G.; Newman, P. Urban fabrics and urban metabolism-From sustainable to regenerative cities. Resour. Conserv. Recycl. 2018, 132, 218-229. [CrossRef]

40. Gallaud, D.; Laperche, B. Circular Economy, Industrial Ecology and Short Supply Chain; ISTE Ltd.: London, UK; John Wiley \& Sons, Inc.: Hoboken, NJ, USA, 2016.

41. Geisendorf, S.; Pietrulla, F. The circular economy and circular economic concepts-A literature analysis and redefinition. Thunderbird Int. Bus. Rev. 2018, 60, 771-782. [CrossRef]

42. de Jesus, A.; Mendonça, S. Lost in transition? Drivers and barriers in the eco-innovation road to the circular economy. Ecol. Econ. 2018, 145, 75-89. [CrossRef]

43. Ellen MacArthur Foundation. Towards a Circular Economy: Business Rationale for an Accelerated Transition. 2015. Available online: https:/ / www.ellenmacarthurfoundation.org/assets/downloads/publications/TCE_Ellen-MacArthur-Foundation_26 -Nov-2015.pdf (accessed on 18 July 2020).

44. Morseletto, P. Restorative and regenerative: Exploring the concepts in the circular economy. J. Ind. Ecol. 2020, 24, 1-11. [CrossRef]

45. Gandy, M. Rethinking urban metabolism: Water, space and the modern city. City 2004, 8, 363-379. [CrossRef]

46. Faraud, C. Urban Metabolism in Practice: The Difficult Implementation of Closing the Loop Approaches, through the Water and Food Cycles in Cities; Dpu Work. Pap. Lies, No. 186; DPU: London, UK, 2017.

47. Naboni, E.; Natanian, J.; Brizzi, G.; Florio, P.; Chokhachian, A.; Galanos, T.; Rastogi, P. A digital workflow to quantify regenerative urban design in the context of a changing climate. Renew. Sustain. Energy Rev. 2019, 113, 109255. [CrossRef]

48. Reed, B. Shifting from 'sustainability' to regeneration. Build. Res. Inf. 2007, 35, 674-680. [CrossRef]

49. Du Plessis, C. Towards a regenerative paradigm for the built environment. Build. Res. Inf. 2012, 40, 7-22. [CrossRef]

50. Zari, M.P. Regenerative Urban. Design and Ecosystem Biomimicry; Routledge: London, UK, 2018. [CrossRef]

51. Korhonen, J.; Honkasalo, A.; Seppälä, J. Circular economy: The concept and its limitations. Ecol. Econ. 2018, 143, 37-46. [CrossRef]

52. Kirchherr, J.; Piscicelli, L.; Bour, R.; Kostense-Smit, E.; Muller, J.; Huibrechtse-Truijens, A.; Hekkert, M. Barriers to the circular economy: Evidence from the European Union (EU). Ecol. Econ. 2018, 150, 264-272. [CrossRef]

53. Cole, R.J.; Oliver, A.; Robinson, J. Regenerative design, socio-ecological systems and coevolution. Build. Res. Inf. 2013, 41, 237-247. [CrossRef]

54. Zari, M.P. Ecosystem services analysis for the design of regenerative built environments. Build. Res. Inf. 2012, 40, 54-64. [CrossRef]

55. Chui, K.T.; Liu, R.W.; Lytras, M.D.; Zhao, M. Big data and IoT solution for patient behaviour monitoring. Behav. Inf. Technol. 2019, 38, 940-949. [CrossRef]

56. Giuliani, M.V. Theory of attachment and place attachment. In Psychological Theories for Environmental Issues; Bonnes, M., Lee, T., Bonaiuto, M., Eds.; Ashgate: Aldershot, UK, 2003; pp. 137-170.

57. Proshansky, H.M. The city and self-identity. Environ. Behav. 1978, 10, 147-169. [CrossRef]

58. Sepe, M. Urban transformation, socio-economic regeneration and participation: Two cases of creative urban regeneration. Int. J. Urban. Sustain. Dev. 2014, 6, 20-41. [CrossRef]

59. Hashem, I.A.T.; Chang, V.; Anuar, N.B.; Adewole, K.; Yaqoob, I.; Gani, A.; Ahmed, E.; Chiroma, H. The role of big data in smart city. Int. J. Inf. Manag. 2016, 36, 748-758. [CrossRef]

60. Bass, T.; Shuderland, E.; Symons, T. Common Knowledge: Citizen-led data governance for better cities. 2020. Available online: https:/ / media.nesta.org.uk/documents/DECODE_Common_Knowledge_Citizen_led_data_governance_for_better_ cities_Jan_2020.pdf (accessed on 18 July 2020).

61. Simonofski, A.; Asensio, E.S.; Wautelet, Y. Citizen participation in the design of smart cities: Methods and management framework. In Smart Cities: Issues and Challenges Mapping Political, Social and Economic Risks and Threats; Visvizi, A., Lytras, M.D., Eds.; Elsevier: Amsterdam, The Netherlands, 2019; pp. 47-62. 